\title{
Anatomy of the endemic palms of the Near and Middle East: archaeobotanical perspectives
}

Anatomie des palmiers endémiques du Proche et Moyen-Orient : applications en archéobotanique

\section{Romain Thomas}

\section{OpenEdition}

\section{Journals}

Édition électronique

URL : http://journals.openedition.org/ethnoecologie/1366

DOI : 10.4000/ethnoecologie.1366

ISSN : 2267-2419

Éditeur

Laboratoire Eco-anthropologie et Ethnobiologie

\section{Référence électronique}

Romain Thomas, «Anatomy of the endemic palms of the Near and Middle East: archaeobotanical perspectives », Revue d'ethnoécologie [En ligne], 4 | 2013, mis en ligne le 31 décembre 2013, consulté le 19 avril 2019. URL : http://journals.openedition.org/ethnoecologie/1366 ; DOI : 10.4000/ ethnoecologie.1366

Ce document a été généré automatiquement le 19 avril 2019

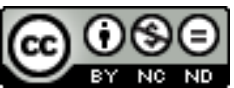

Revue d'ethnoécologie est mis à disposition selon les termes de la licence Creative Commons Attribution - Pas d'Utilisation Commerciale - Pas de Modification 4.0 International. 


\section{Anatomy of the endemic palms of the Near and Middle East: archaeobotanical perspectives}

Anatomie des palmiers endémiques du Proche et Moyen-Orient : applications en archéobotanique

Romain Thomas

\section{Introduction}

1 Five palm genera are found in the Near and Middle East (Dransfield et al. 2008): Chamaerops, Hyphaene, Medemia, Nannorrhops and Phoenix. All belong to the Coryphoideae subfamily. In these arid regions, where the arborescent vegetation is neither varied nor abundant, palms play an important role in the local economies, as they are well adapted to the dry climatic conditions. One of the most important crops of these regions, the date palm, is found within this family.

2 The date palm (Phoenix dactylifera L.), a key species in the oasis agrosystem, is cultivated for its numerous useful products: fruits, leaves for roofing and basketry, fibres for ropes and "wood" for construction and fuel (Munier 1973). The stem's main use is for its ligneous tissue, which is not of high quality because of the monocotyledonous vasculature (fibrovascular bundles), but has great tensile strength useful in poles, beams, rafters, lintels, girders or pillars. For this purpose they can be used whole or split in halves or quarters. Hollowed out half trunks are used as conduits for water, or in shorter lengths as mangers and troughs. Every year, under normal growth conditions, an average of 12 to 15 new leaves are formed by the palm and consequently the same amount can be expected to be cut as a by-product from date palm cultivation (Barreveld 1993). Regular cutting, or pruning of older leaves is used to maintain the vigour of the tree and enhance fruit 
production (Richardson \& Dorr 2003). Petioles are used as roofing and to make furniture, leaves are used for fuel.

The doum palm, Hyphaene thebaica (L.) Mart., is locally very important, particularly to subsistence farmers. As for Phoenix, the petiole is a secondary product. They are mainly collected from dry mature leaves and are used for building, furniture and fuel. The leaves are used for thatch and as a source of fibre for plaiting (Vartavan \& Asensi Amoros 1997, Amwatta 2004). Its wood can be used for making boats or for carpentry (Manniche 1989). All fallen parts of the palms are used as fuel (Dransfield et al. 2008).

Nannorrhops ritchiana (Griff.) Aitch. is used as a source of fibre for weaving and rope making (Thomas et al. 2012). It is one of the hardiest palms (Dransfield et al. 2008). It is for this property that the tallest specimens can be used for building.

Chamaerops fibres have been used for cordage and woven articles but there is no record of the use of the stem.

Because of the rarity of Medemia, few records of this genus exist. Archaeologically, it was found mainly in the form of fruits and seeds (de Vartavan \& Asensi Amoros 1997), but also in the form of matting using the leaves (Newton 2001). Today, it grows in Egyptian Nubia and northern Sudan but in ancient Egypt it was a garden tree. Johnson (1989) writes that Medemia may have had the same range of uses as Hyphaene, but its main use seems to have been the leaves for matting and rope-making (Beccari 1924, Keimer 1951, Greiss 1957). Over-exploitation may partly account for its rarity (Dransfield et al. 2008).

7 During Prehistory and Antiquity, palms of these arid regions also played an important role in the economies of the Near and Middle East. However, palm remains have mostly been identified at the family level - usually as coming from date palm - but little attempt (Greiss 1957, Fahn 1986, Neumann et al. 2000) has been made to distinguish: (i) the different genera; and (ii) the stem tissue from the woody parts of the leaf. The identification of the different parts of the palm (petiole vs. stem) is important in order to understand practices of date palm exploitation and management of date palm gardens in the past (Tengberg 2012). In the Results section I provide anatomical descriptors for distinguishing between the different palm genera and different parts of the palms. Stem anatomical descriptors as well as anatomical descriptions are compiled in the computeraided identification software $\mathrm{Xper}^{2}$ available on Internet (Palm-ID database: Thomas 2011b, Thomas \& De Franceschi 2013).

\section{Material and methods}

\section{Taxa examined}

Only five palm genera are found in the Middle and the Near East (Dransfield et al. 2008): Chamaerops, Hyphaene, Medemia, Nannorrhops and Phoenix. The stems and petioles of 16 specimens of these genera were sampled from wild plants, cultivated plants (Fairchild Tropical Botanic Garden, Montgomery Botanical Center), and specimens in herbaria and xylaria of the Royal Museum for Central Africa (Tervuren, Belgium) (MRAC), the Economic botany collection of Kew (UK) (K) and the Xylothèque du Muséum national d'histoire naturelle in Paris (France) (P). Only the stem of Medemia was not sampled because of the relative rarity of this species. 
Chamaerops humilis L.; Pers., R. Thomas sn. C. humilis; MRAC, Tw 40121, R. Dechamps \& H. Doutrelepont sn. C. humilis; P, P00395018. C. humilis; P, P00397191 B202. Hyphaene petersiana Klotzsch ex Mart.; Pers., R. Thomas sn. H. thebaica (L.) Mart.; FTG, 4351, J.B. Fisher. H. thebaica; FTG, 57538A, J.B. Fisher. H. thebaica; P, P00417274. H. thebaica; Pers., R. Thomas sn. Hyphaene sp. Gaertn.; FIP, R. Thomas sn. Medemia argun (Mart.) Wurttenb. ex H.Wendl.; MBC, 971578E. Phoenix dactylifera L.; K, EBC 26329. P. dactylifera; Pers., $R$. Thomas sn. P. reclinata Jacq.; MRAC, Tw 44588, F. Malaisse sn. P. sylvestris (L.) Roxb.; K, EBC 26340. Nannorrhops ritchiana (Griff.) Aitch.; Pers., R. Thomas sn.

\section{Anatomical preparations}

Samples collected from a live stem, were just air-dried to prevent fungal growth. For some specimens, we preserved and softened the material in a solution (2:1:1) $95 \%$ ethanol: glycerol: water. Various techniques were used for anatomical preparations (Thomas \& De Franceschi, 2013). For the very hard material we used an adapted method of petrographic thin sectioning. First, specimens were embedded in an unsaturated epoxy resin - araldite 2020 (XW 396/XW 397) standard mixture (Huntsman, Basel, Switzerland). Then, before sectioning and polishing, two embedding methods were followed according to the timing of the preparation: (i) embedding with resin for at least seven days at $40^{\circ} \mathrm{C}$; (ii) embedding with resin for 1 hour at $80^{\circ} \mathrm{C}$. Finally, the embedded specimens were stuck with the same resin on a frosted slide and polished to obtain the suitable thickness (15 to $30 \mu \mathrm{m})$ for microscopic observation. The glass covering was mounted using the same araldite resin as for embedding. For soft materials, transverse (TS) and longitudinal (LS) sections were obtained with a sliding microtome (Reichert, Austria), and sometimes stained with iodine-green or safranin/fast green coloration. For some samples, we made direct observations on surfaces polished with a succession of increasingly fine abrasives. This method allowed microscopic observations with the use of a reflected light (episcopic) microscope (BXFM Olympus, Tokyo, Japan). Preliminary polishing was done using macrogrit sandpaper 80 (in the international standard ISO 6344, equivalent to $200 \mu \mathrm{m}$ ) and final polishing was done using microgrit $2400(7 \mu \mathrm{m})$. Complete transverse sections of the stem were prepared for narrow stems; subsections covering the diagnostic parts of the stem (i.e. cortical, subcortical and central part) were prepared for wider stems.

\section{$\mathrm{Xper}^{2}$ and the computer-aided identification}

11 All the stem descriptions were compiled in the computer-aided identification (CAI) software Xper ${ }^{2}$ (Ung et al. 2010; Vignes-Lebbe et al. 2011), an interactive identification tool available on Internet: http://www.infosyslab.fr/Palm-ID/ (Thomas 2011b, Thomas \& De Franceschi, in press). Xper ${ }^{2}$ is a management tool for taxonomic descriptions that allows editing standardised descriptions (the descriptors and their states, logical dependencies between descriptors and groups of descriptors). This knowledge base can be used by palaebotanists and archaeobotanists as an interactive identification tool available on the Web, as it already exists for wood with the InsideWood Database (InsideWood 2004). In the Palm-ID knowledge base, taxa (subfamily, tribe and genera) of the palm family are described by 32 stem descriptors in 7 groups (e.g., cortex, central cylinder, fibrovascular bundles, etc.) with a total of 107 states. 


\section{Results}

\section{Stem (Plate I)}

Plate I. Stem anatomy (transverse sections, or polished surfaces)

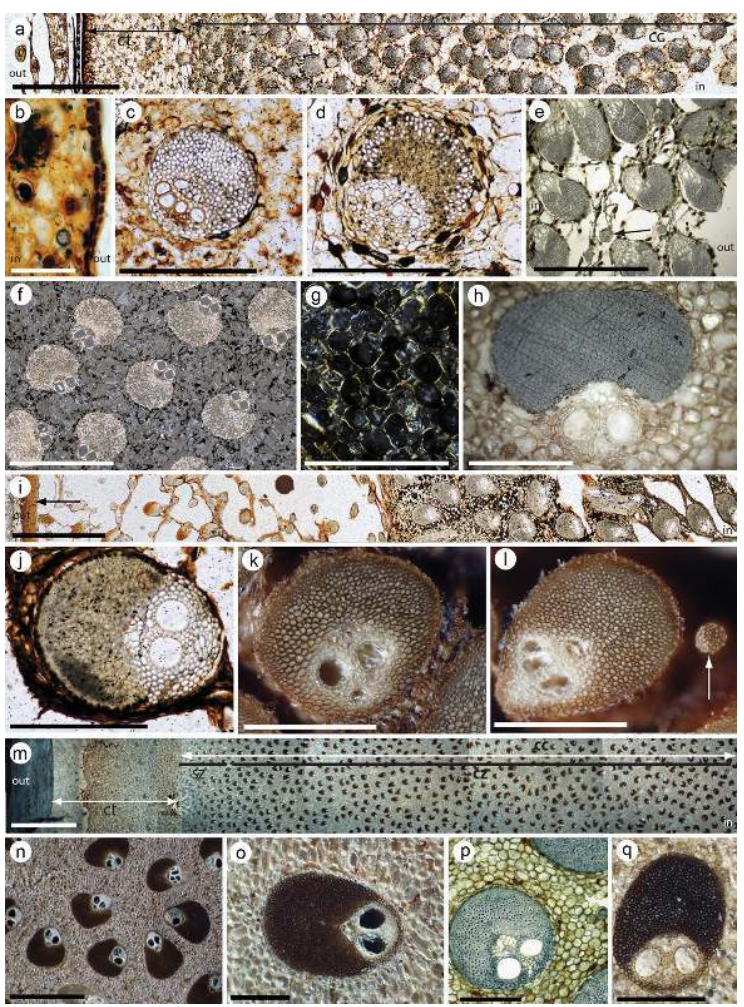

A-E. Chamaerops humilis. A. General organization of the stem with a wide cortex (ct) and a homogeneous central cylinder (cc) with scattered fibrovascular bundles (fvb). B. Detailed view of the epidermis with tangentially elongated cells. C-E. Lunaria (c and d) and Reniforma (e) Fvb with three to four vessel elements. Fibrous bundles present (arrow, e). F-g. Hyphaene thebaica. Central zone of the central cylinder (homogeneous central cylinder), Reniforma fvb (auricular sinus present) with two vessel elements. The ground parenchyma is made of compact and spheroid to slightly elongate cells (g). H. Hyphaene sp. Same anatomy as before. I-L. Nannorrhops ritchiana. I. General organization of the stem (wide cortex) and suberized zone (arrow). J-L. Fibrovascular bundles, Lunaria (j) to Vaginata (kl) with two wide metaxylem elements. Fibrous bundles are present (l, arrow), but not well developed. M-o. Phoenix dactylifera. $\mathbf{M}$. General organization of the stem with a wide cortex and a homogeneous central cylinder. $\mathbf{N}-\mathbf{o}$. Vaginata fvb with two vessel elements, ground parenchyma compact with spheroid cells. P. P. reclinata. Reniforma fvb with two vessel elements, spheroid ground parenchyma cells. Q. P. sylvestris. Same organization as before. Key to labelling: cc, central cylinder; ct, cortex; cz, central zone; sz, subcortical zone. Scale bars: $\mathrm{m}, 1 \mathrm{~cm}$; a, i, n, $2 \mathrm{~mm}$; e, f, 1 mm; c, d, g-h, j-l, o-q, 500 $\mu \mathrm{m} ; \mathrm{b}, 100 \mu \mathrm{m}$.

(c) R. THOMAS

12 As described by Tomlinson $(1961,1964,1990)$ and Zimmerman and Tomlinson (1972), the stem consists of a central cylinder and a cortex. The outermost layer is the periderm, which is replaced by other superficial protective tissues that become suberised or sclerified in old stems. Under this specific layer is a cortex (Plate I a, m), more or less developed according to genera. The central cylinder is clearly demarcated from the cortex by a peripheral sclerotic subcortical zone (sz, Plate I m) with many more or less crowded vascular bundles (Waterhouse \& Quinn, 1978). The zone of transition sometimes shows a change in fibrovascular bundles density and structure toward the central zone (cz, 
Plate I m) of the stem, where bundles are less densely arranged (Waterhouse \& Quinn 1978). The ground tissue of the central zone consists of compact or lacunose parenchyma and becomes thick-walled and lignified with age. In the central cylinder, fibrous bundles are found in some genera. Parthasarathy and Klotz (1976a and 1976b) and more recently Tomlinson et al. (2011) presented a detailed summary of the anatomy of the stem.

\section{The palm fibrovascular bundle (fvb)}

Figure 1. Palm fibrovascular bundles (fvb)

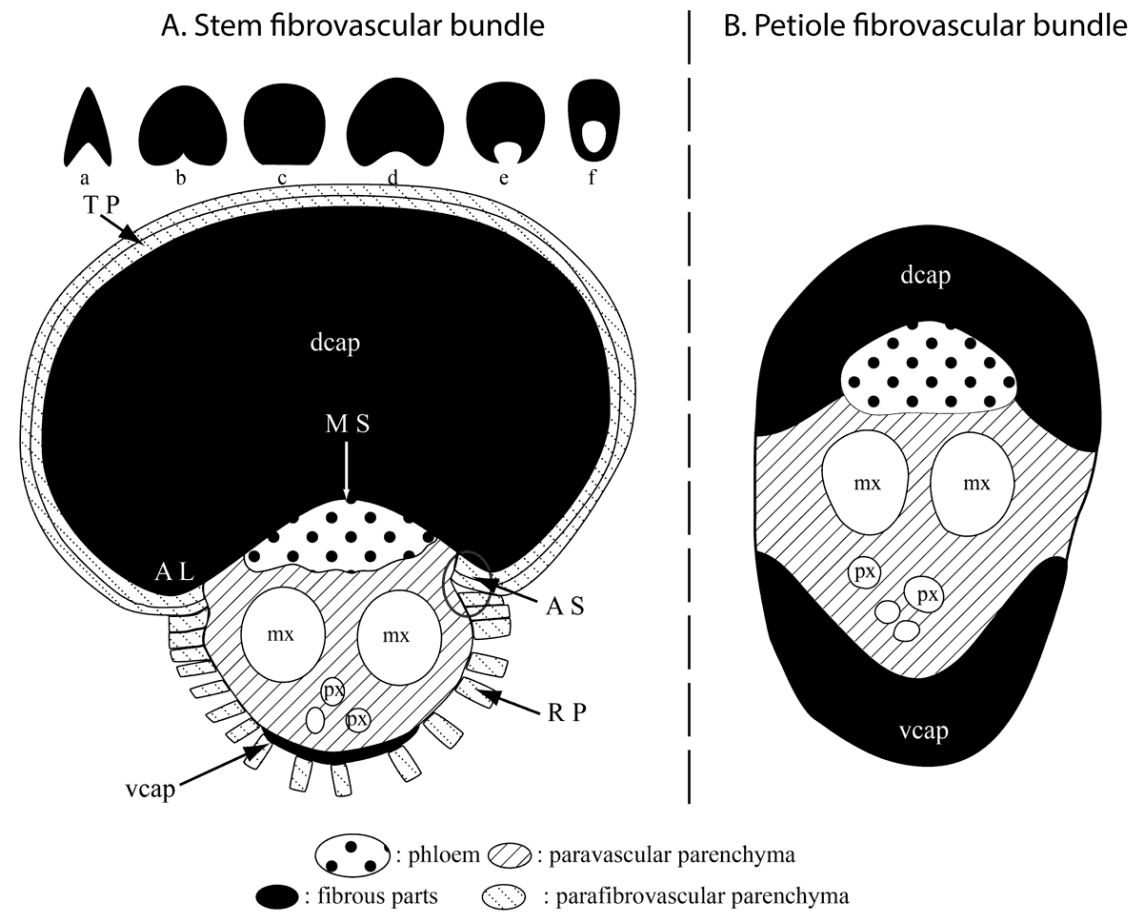

A. STEM (from Thomas 2011a). B. PEtiole. Vascular part with metaphloem, metaxylem elements and paravascular parenchyma. The stem fvb presented here (A) has a Reniforma fibrous part. But other types of fibrous parts adjacent to the phloem are encountered in palms: A. Sagittata, B. Cordata, C. Complanata, D. Reniforma, E. Lunaria, F. Vaginata. AL: auricular lobe; AS: auricular sinus; dcap: fibrous part external to the phloem (ex-fibrous dorsal cap); MS: median sinus; mx: metaxylem; px: protoxylem; RP: radiating parenchyma; TP: tabular parenchyma; vcap: fibrous part external to the xylem (ex-fibrous ventral cap).

MODIfIED FROM THOMAS (2011 A)

The fvb are made of a vascular part and a fibrous part (Figure 1A.). The vascular part contains: (i) protoxylem elements, sometimes well developed in fvb connecting a leaf (the leaf trace); (ii) one to five and more (depending on the species) wide metaxylem elements; (iii) phloem in a recess of the fibrous part (the median sinus). The fibrous sheath is always developed external to the phloem and shows some variability (Reniforma, Lunaria, Vaginata). Sometimes a fibrous cap is developed external to the protoxylem or the xylem elements, and in other cases the vascular part is included within the fibrous part. There is a basipetal fibre wall thickening seen in the multi-layered structure of the cell wall. Fibres keep depositing secondary walls during most of their lifetime. In these genera, phytoliths are globular echinate and well developed throughout the central cylinder. Tomlinson et 
al. (2011) and Thomas (2011 a, b) present a detailed anatomy of the studied genera. Within the stem, discrimination between the five genera is possible (Thomas $2011 \mathrm{a}, \mathrm{b}$ ). In Table 1 only the anatomical descriptors that bear taxonomic information are presented.

Table 1. Stem taxonomic descriptors

\begin{tabular}{|c|c|c|c|c|c|c|}
\hline Genus & $\begin{array}{l}\text { Stenzel } \\
\text { classification } \\
\text { of fibrous part } \\
\text { of fvb }\end{array}$ & $\begin{array}{l}\text { Vessel } \\
\text { elements } \\
\text { per fvb }\end{array}$ & $\begin{array}{l}\text { Fibrous } \\
\text { bundles } \\
\text { in central } \\
\text { cylinder }\end{array}$ & $\begin{array}{l}\text { Developed } \\
\text { cortex of } \\
\text { the stem }\end{array}$ & $\begin{array}{l}\text { Ground } \\
\text { parenchyma of } \\
\text { the central } \\
\text { cylinder }\end{array}$ & $\begin{array}{l}\text { Fibrous } \\
\text { part } \\
\text { adjacent } \\
\text { to the } \\
\text { xylem }\end{array}$ \\
\hline Chamaerops & $\begin{array}{l}\text { Lunaria to } \\
\text { Reniforma }\end{array}$ & (3)-4 & $\mathbf{P}$ & $\begin{array}{l}\mathrm{P} \quad \text { (several } \\
\mathrm{mm})\end{array}$ & $\begin{array}{l}\text { Spheroid and } \\
\text { compact } \\
\text { (sometimes } \\
\text { slightly } \\
\text { elongate), } \\
\text { lacunae } \\
\text { (collapsing cells), } \\
\text { slightly } \\
\text { developed }\end{array}$ & A \\
\hline Hyphaene & Reniforma & 2 & A & $\mathrm{P}$ & $\begin{array}{l}\text { Spheroid and } \\
\text { compact } \\
\text { (sometimes } \\
\text { slightly elongate) }\end{array}$ & A \\
\hline Nannorrhops & $\begin{array}{l}\text { Lunaria to } \\
\text { Reniforma }\end{array}$ & 2 & $\mathbf{P}$ & $\mathrm{P}$ & $\begin{array}{l}\text { Spheroid and } \\
\text { compact. } \\
\text { Sometimes } \\
\text { elongated cells } \\
\text { arranged radially } \\
\text { around each fvb }\end{array}$ & $\mathrm{P} / \mathrm{A}$ \\
\hline Phoenix & $\begin{array}{l}\text { Vaginata to } \\
\text { Lunaria }\end{array}$ & 2 & A & $\mathrm{P}$ & $\begin{array}{l}\text { Spheroid and } \\
\text { compact } \\
\text { (sometimes } \\
\text { slightly } \\
\text { elongate). }\end{array}$ & $\mathbf{P}$ \\
\hline
\end{tabular}

Chamaerops (Plate I a-e). The cortex is wide with a peripheral zone sometimes suberised. Epidermal cells are tangentially elongated (Plate I b). Fibrovascular bundles are Lunaria or Reniforma with a high density, so that they appear almost congested (Plate I c-e). The vascular part is separated from the fibrous part and contains three to four metaxylem elements. Fibrous bundles are present, but sometimes only slightly developed. The ground parenchyma is made of spheroid to slightly elongated cells and compact with sometimes few and small lacunae in old stems (as for Nannorrhops, parenchyma may become collapsed in the central zone, Plate Ie). Diagnose: Wide cortex (several millimetres), Cocos-Type, Lunaria to Reniforma fvb, 3-4 metaxylem elements, ground parenchyma (slightly developed) compact and spheroid, fibrous bundles present. 
Hyphaene (Plate I $\mathrm{f}-\mathrm{h})$. The cortex is very wide ( $1 \mathrm{~cm}$ and more) and, in mature stems, divided into two parts. The outer zone, of varying width, has thick-walled suberised and sclerified cells without specific organisation and fibrous bundles; the inner zone has an unspecialised ground parenchyma. A sort of periderm may be developed in old stems. The general organisation of the central cylinder is similar to that of Phoenix: Cocos-Type). Fibrovascular bundles are Reniforma with an excluded vascular part and two vessels elements with little paravascular parenchyma. Sometimes, the fvb may appear Reniforma without auricular sinus (this depends on the state of development of the stem, Plate I f). Tabular parenchyma is present. The phloem is not partitioned. The ground parenchyma is compact, made of spheroid to slightly elongated cells. No fibrous bundle is observed in the ground parenchyma. Diagnose: Cocos-Type, Reniforma fvb, 2 metaxylem elements, few paravascular parenchyma, ground parenchyma spheroid to slightly elongate and compact.

Nannorrhops (Plate I $\mathrm{i}-1)$. The cortex is wide $(>5 \mathrm{~mm}$ ) with a suberised zone (Plate I i arrow ). An alignment of 4-6 cells is locally observed at the periphery of the cortex. The central cylinder is homogeneous (Cocos-Type). Fibrovascular bundles with two metaxylem elements have a Lunaria to Reniforma fibrous part (almost no observation of Vaginata $\mathrm{fvb}$, Plate I $\mathrm{j}-1)$. The fibrous part adjacent to the xylem is much more visible on polished or carbonised specimens than on the specimens observed in thin section (Plate I j-k and Figure 3 a). The ground parenchyma is made of spheroid cells but may appear with a tangential elongation around the fvb of the subcortical zone. This ground parenchyma may become collapsed in the central zone, and is thus not easily observable in old stems (Plate I i). Fibrous bundles are present with a density of $<30 / \mathrm{cm}^{2}$ (Plate I l). Diagnose: Wide cortex, Cocos-Type, fvb Lunaria to Reniforma, 2 metaxylem elements, fibrous part adjacent to the xylem is sometime present, fibrous bundles present.

Phoenix (Plate I m-q). The general stem organisation is highly homogeneous: there are few differences in the structure and the density of the fibrovascular bundles between the central zone and the subcortical zone; this specific organisation is called Cocos-Type (Thomas \& De Franceschi, 2013). The cortex is very thick (Plate I m) without a suberised outer layer but with slightly sclerified parenchyma cells. The central cylinder is made of a subcortical zone with many (but not crowded) small fibrovascular bundles, which become quickly wider in the peripheral zone. Their size and shape are constant toward the central zone. Fibrovascular bundles are more or less circular in transverse section with a Vaginata to Lunaria fibrous part depending on the fibres' development. Fibrovascular bundles have two vessel elements. Tabular parenchyma is present as one to two layers. The paravascular parenchyma is poorly developed. The ground parenchyma is compact with spheroid to slightly elongated cells (Plate In-q). Sometimes, small lacunae are developed in the old stems. Diagnose: Cocos-Type, Lunaria fvb, 2 metaxylem elements, ground parenchyma spheroid to slightly elongate and compact.

\section{Petiole (Plate II)}


Plate II. Petiole anatomy (transverse sections, iodine green).

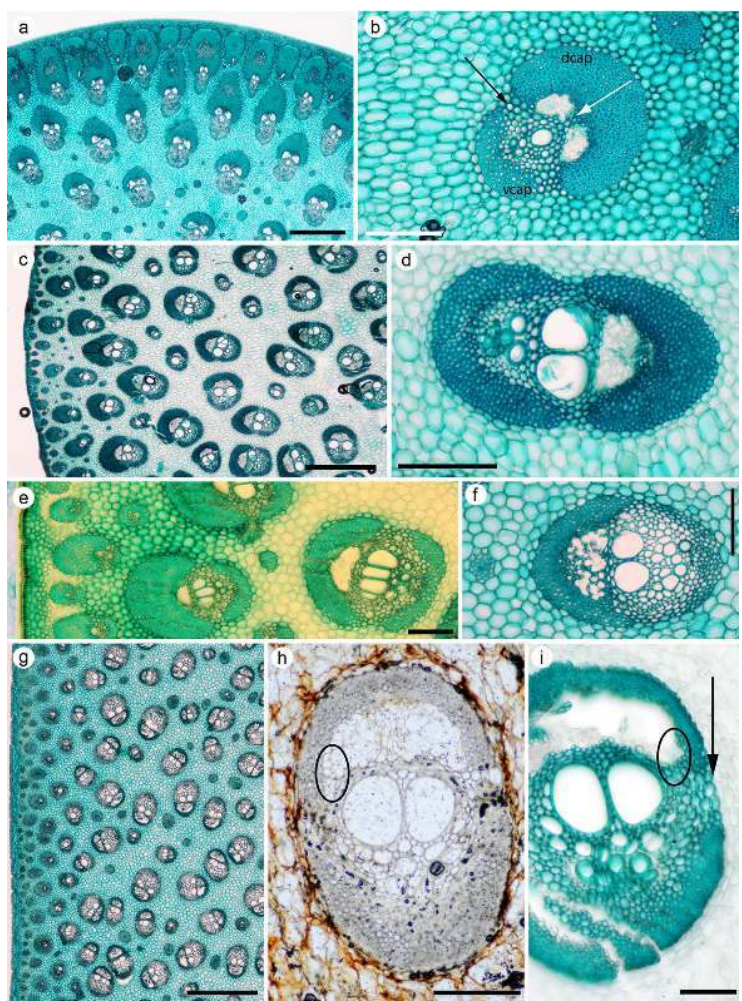

A-B. Chamaerops humilis. Abaxial side (a) and detailed view of fvb (b). Fibrous parts adjacent to the xylem and phloem are well developed but not in contact (black arrow). Partitioned phloem in two strands (white arrow). Fibrous bundles presents. C-D. Hyphaene thebaica. Abaxial side (c) and detailed view of a fvb with two vessel elements and one phloem strand. E. Medemia argun. Same organization as Hyphaene. F-g. Nannorrhops ritchiana. Adaxial zone (g) and fvb (f) made of two vessel elements, more than two vessels per fvb are visible on $\mathrm{g}$. Phloem with a lot of sclerotic cells. H-I. Phoenix dactylifera. Fibrovascular bundles with two vessel elements. Fibrous part adjacent to the phloem and xylem are well developed but not in contact (black arrow). Phoenix phloem is distinctive by developing extension towards the xylem (circles) but not always present ( $h$, transverse section without staining).

\section{(c) R. THOMAS}

The anatomy of the leaf axis presents a high variability when moving from the base (petiole) to the apex of the leaf (rachis). I present here the anatomy of the petiole only (Figure 2). 
Figure 2. General organisation of a petiole (transverse section). Nannorrhops, iodine green

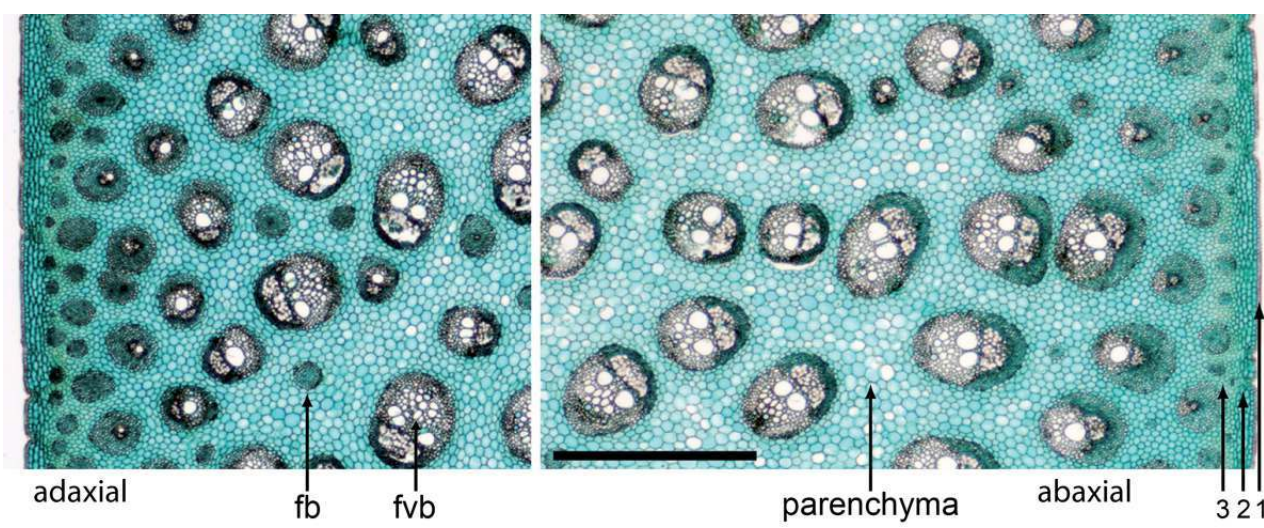

1: epidermis, 2: hypodermis, 3: chlorenchyma, fb: fibrous bundle, fvb: fibrovascular bundle. Scale bar: 1 $\mathrm{mm}$

(C) R. THOMAS

19 The epidermis is highly cutinised. Stomata are frequent and often sunken, sometimes aborted. They preserve their anatomical structure, and so their taxonomic significance (Tomlinson 1961; Tomlinson et al. 2011). The hypodermis is present and lies on a parenchyma of palisade type with very thin walls (chlorenchyma). Fibrous bundles are scattered at the periphery of the abaxial side and are more densely distributed at the periphery of the adaxial side. Fibrovascular bundles (Figure 1B) are made of a fibrous part adjacent to the phloem and of a fibrous part surrounding the xylem and have one, two or more wide metaxylem elements. The two fibre sheaths are not in contact and are separated by parenchymatous cells (Plate II, b black arrow). The phloem is either in one strand or partitioned into two strands by sclerified cells. Fvb have a random orientation in the central zone and are normally oriented at the abaxial side (phloem towards the outside). The ground parenchyma is made of spheroid cells without lacunae. Cells surrounding each fvb could become markedly dilated radially. Tabular parenchyma may be present around the fvb. Fibrous bundles are almost absent except at the base of the petiole where they are frequently found. However, fibrous bundles are present in the chlorenchyma. Thomas et al. (2012) made a detailed study of the leaf phytoliths found in leaves. Tomlinson (1961) and Tomlinson et al. (2011) present a detailed anatomy of the studied genera. Table 2 presents only the anatomical descriptors that bear taxonomic information.

Table 2. Petiole taxonomic descriptors.

\begin{tabular}{|l|l|l|l|}
\hline Genus & $\begin{array}{l}\text { Vessel elements } \\
\text { per fvb }\end{array}$ & $\begin{array}{l}\text { Fibrous bundles in } \\
\text { central ground tissue }\end{array}$ & Phloem strand \\
\hline Chamaerops & $(1),>2$ & P & 2 (sclerotic partition) \\
\hline Hyphaene; Medemia & 2 & A (occasional) & 1 \\
\hline Nannorrhops & $\begin{array}{l}2,>2 \quad \text { (abundant } \\
\text { protoxylem) }\end{array}$ & P (frequent) & 1 , sclerotic cells \\
\hline
\end{tabular}




\begin{tabular}{|l|l|l|l|}
\hline Phoenix & 2 & Widely scattered & $\begin{array}{l}1 \quad \text { (occasional sclerotic } \\
\text { partition or sclerotic cells) }\end{array}$ \\
\hline
\end{tabular}

Chamaerops (Plate II a-b). The epidermis has strongly cutinised outer periclinal walls and anticlinal walls (Tomlinson et al. 2011). There are two to three layers of hypodermis. The fibrous sheath is distinctively interrupted at the metaxylem level (Plate II b black arrow). Peripheral fvb have one metaxylem element, those of the centre have two to four vessels. The phloem strand is divided by a central sclerotic partition. Fibrous bundles are present. Ground parenchyma cells could be dilated radially around the fvb.

Hyphaene (Plate II c-d) and Medemia (Plate II e). There are numerous sunken stomata, sometimes aborted and a thick cuticle. There are three to four layered hypodermis of irregular cells with thick lignified walls. Chlorenchyma contains fvb and fibrous bundles. The ground parenchyma is compact and made of spheroid cells. The fibrous sheath is interrupted at the metaxylem level. The fibrovascular bundles have two metaxylem elements. The phloem is in one strand with few or no sclerotic cells. Fibrous bundles are abundant at the petiole periphery.

Nannorrhops (Plate II f-g). The hypodermis is well developed (4-6 layers of sclerotic cells). The fibrous sheath is interrupted at the metaxylem level but less distinctly than the other genera described here. This fibrous sheath is more developed above the phloem than above the xylem (sclerified parenchyma may also be present in the fibrous part adjacent to the xylem). There are two metaxylem elements per fvb. The protoxylem is highly developed in this genus (Plate II f). The phloem is in a single strand, including numerous irregularly distributed sclerotic cells. Fibrous bundles present.

Phoenix (Plate II h-i). The fibrous sheath is interrupted at the metaxylem level. Two metaxylem elements per fvb. The phloem is in one strand sometimes including sclerotic cells. Occasionally, in some petioles, these cells make a sclerotic partition, so that the phloem is in two strands. In the observed specimens, the phloem presents two extensions toward the xylem (Plate II h-i).

\section{Discussion}

\section{Differences between stem fvb and petiole fvb}

The previous results show that the anatomy of a stem fvb presents some differences with a petiole fvb. These differences are based on the fibrous sheath (fibrous part adjacent to the phloem, dcap, or the xylem, vcap). (i) For stem fvb, the fibrous part adjacent to the phloem is always well developed in the studied genera (several times larger than the vascular part) even in the central zone of the central cylinder, whereas in the petiole fvb is only slightly developed (less developed than the vascular part), except for those of the peripheral zones. (ii) For the stem fvb, the fibrous part adjacent to the xylem is mostly absent (always absent in Hyphaene and in Chamaerops), very slightly developed for Nannorrhops or present for Phoenix. This fibrous part is always developed in the petiole and is made of highly lignified cells. (iii) The phloem of petiole fvb is more developed than that of the stem fvb and could present sclerotic cells. (iv) At the level of the metaxylem, a discontinuity between these two fibrous parts is always prominent for the petiole fvb. 


\section{Differences between the stems of the different Phoenix species} discriminate the different species of the Phoenix genus as all the analysed specimens have exactly the same anatomy. However, even if the anatomy of the vegetative part does not allow the identification of the different Phoenix species based on stem or petiole fragments, it appears that the different species have different seed morphologies (Terral et al. 2012).

\section{On the phytolith discrimination}

Petiole and stem anatomical studies are not the only methods to identify palms remains Phytolith analysis could provide interesting results (Albert et al. 2009, Delhon \& Orliac 2010, Thomas et al. 2012), even though the discrimination between the different genera is often very difficult (Thomas 2011a).

\section{Limits of the identification methods}

All these anatomical results have been obtained by the observation of living specimens. However, even if all the descriptors cited above are not visible on the fossil or sub-fossil remains, identification is still possible. The archaeological remains are often made of small charcoal fragments, thus only few fvb associated with ground parenchyma cells are preserved. Therefore, a tentative identification method (Table 1, Table 2) from the fvb and the ground parenchyma is proposed in this article. Because of the variability of the stem, the most useful and solid descriptors are (adapted from Thomas \& De Franceschi 2013): general stem pattern (all the genera described here have a Cocos-Type organisation); shape of fibrous part in TS (Reniforma, Lunaria...); number of wide metaxylem elements per fvb; type of phytoliths (all the genera described here have globular echinate phytoliths); ground parenchyma of the central cylinder. Concerning the petiole, the descriptors are: number of wide metaxylem elements per fvb; fibrous bundles in central ground tissue; number of phloem strands (and presence of sclerotic cells). As shown in Tables 1 and 2, it is possible to discriminate most of these genera using these descriptors. Hyphaene and Medemia are too closely related to establish a robust distinction between these genera. Furthermore, we observe that these anatomical descriptors do not vary between the different specimens of a species or between the different species of a genus. Moreover, it is sometimes possible to discriminate small fragments: with the assumption of the limited taxonomic sampling in the studied geographical zone, a small fragment with some fibrovascular bundles associated with ground parenchyma makes identification possible. However, identification of the woody parts of the palm is more suitable with large fragments including the central and the subcortical zone of the stem central cylinder and with several fvb. As for wood, even if desiccation and carbonisation modify the anatomical structure (a general volumetric shrinkage and a wall separation), identification is still possible (Figure 3). 
Figure 3. Archaeological stem and petiole fibrovascular bundles
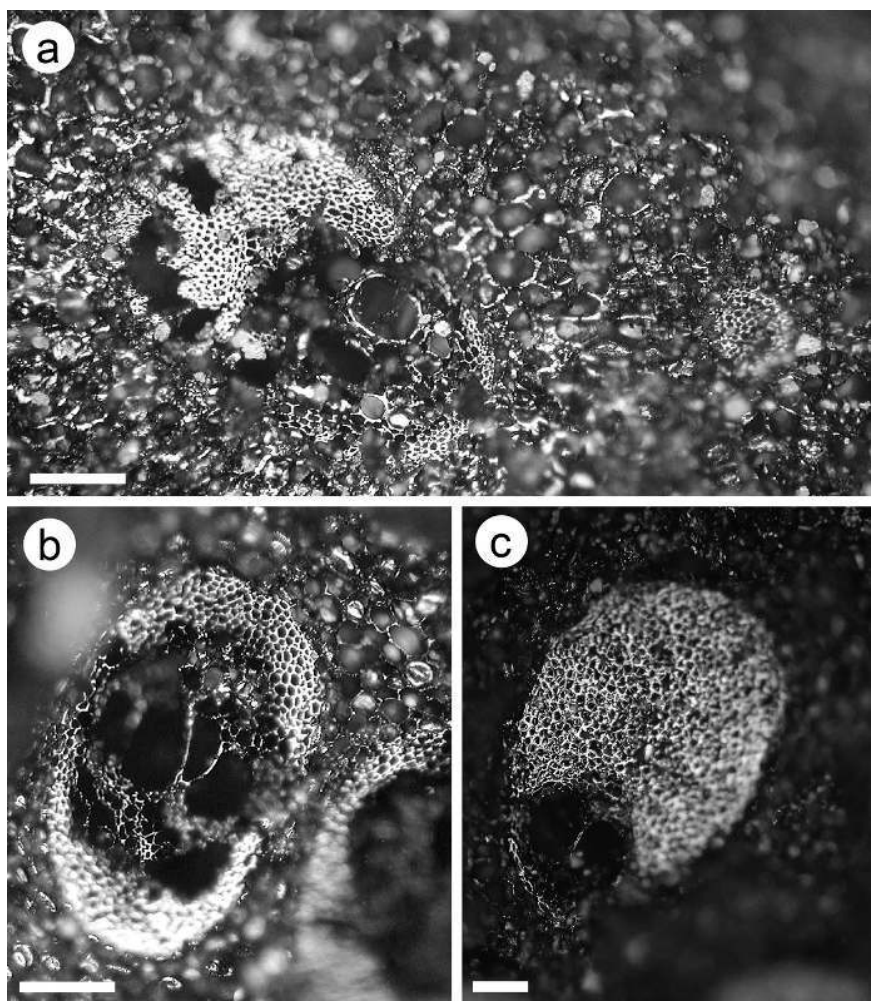

a. Nannorrhops stem fvb. b. Phoenix petiole fvb. c. Phoenix stem fvb. See Results and Discussion for a complete description and Plates 1 and 2 for comparison with the living specimens (Charcoal fragments from unpublished studies of Kush (Ras al-Khaimah, UAE), 4th-17th/18th centuries AD).

(c) R. THOMAS

Anatomical variations within the different vegetative parts of the five palms of the Near and Middle East (Chamaerops, Hyphaene, Medemia, Nannorrhops, Phoenix) allow the distinction between stem and petiole and the identification at the genus level. Bouchaud et al. (2012) use these results in order to identify charcoal in the archaeological site of Madâ'in Sâlih (Saudi Arabia, 2nd century B.C. until the 7th century A.D.). Their results show that petioles are more widely used than stems for fuel purposes and confirm the modern sources indicating petioles as a good fuel (Munier 1973) and that the local population probably practiced pruning to maintain their palm grove.

\section{BIBLIOGRAPHIE}

Albert R.M., Bamford M.K. \& Cabanes D. 2009 - Palaeoecological significance of palms at Olduvai Gorge, Tanzania, based on phytolith remains. Quaternary International 193 (1-2) : 41-48.

Amwatta C. 2004 - Diversity of use of Doum Palm (Hyphaene compressa) Leaves in Kenya. Palms 48 (4) : 184-190. 
Barreveld W. 1993 - Date palm products. FAO agricultural services bulletin 101 : 1-216.

Beccari O. 1924 - Palme della tribù Borasseae. Opera postuma. Curante Ugolino Martelli. Firenze, G. Passeri.

Bouchaud C., Thomas R., Tengberg M. 2012 - Optimal use of the date palm tree (Phoenix dactylifera L.) during Antiquity: Anatomical identification of plant remains from Madâ'inSâlih (Saudi Arabia). In Badal E., Carrion Y., Macias M., Ntinou M. (Ed.) Wood and charcoal. Evidence for human and natural history. Proceedings of the 5th International Meeting of Charcoal Analysis. Saguntum extra 13, Valencia, 173-186.

Delhon C. \& Orliac C. 2010 - Les palmiers disparus de l'île de Pâques: Nouvelles données radiocarbones et phytolithiques. In Valentin F. \& Hardy M. (Dir), Hommes, milieux et traditions dans le Pacifique Sud. Paris, Éditions De Boccard : 181-197.

Dransfield J., Uhl N., Asmussen-Lange C.B., Baker W.J., Harley M.M \& Lewis C.E. 2008 - Genera Palmarum: The Evolution and Classification of Palms. $2^{\text {nd }}$ edition. Kew, Kew Publishing.

Fahn A. 1986 - Wood anatomy and identification of trees and shrubs from Israel and of adjacent regions. Jérusalem, Israel Academy of Sciences \& Humanities.

Greiss E. 1957 - Anatomical identification of some Ancient Egyptian plant materials. Cairo, Institut d'Égypte.

Johnson D. 1989 - Present and potential economic uses of palms in arid and semi-arid areas. In Wickens G. \& Goodin J.R. (Eds), Plants for arid lands, Proceedings of the Kew International Conference on Economic Plants for Arid Lands Held in the Jodrell Laboratory. Unwin Hyman Kew, Royal Botanic Gardens.

Keimer L. 1951 - Notes prises chez les Bisarin (Bédouins) et les Nubiens d'Assouan, première partie. $1^{\text {ère }}$ note, Le palmier du désert des Bisarin. Bulletin de l'Institut d'Égypte, 32 : 49-64.

Manniche L. 1989 - An Ancient Egyptian Herbal. London, British Museum Press.

Munier P. 1973 - Le palmier dattier. Collection Techniques agricoles and productions tropicales, xxiv. Paris, G.P. Maisonneuve \& Larose.

Neumann K., Schoch W., Detienne P. \& Schweingruber F. 2000 - Woods of the Sahara and the Sahel: an anatomical atlas. Berne, Paul Haupt.

Newton C. 2001 - Le Palmier Argoun Medemia argun (Mart.) Württemb. ex Wendl. In Encyclopédie religieuse de l'Univers végétal, Croyances phytoreligieuses de l'Égypte ancienne (ERUV) II. Orientalia Monspeliensia XI, 141-153. Montpellier.

Parthasarathy M. \& Klotz L.H. 1976a - Palm “Wood" - ii. Ultrastructure Aspects of Sieve Elements, Tracheary Elements and Fibers. Wood Science and Technology, $10: 247-271$.

Parthasarathy M. \& Klotz L.H. 1976b - Palm “Wood” - i. Anatomical Aspects. Wood Science and Technology, $10: 215-229$.

Richardson N. \& Dorr M. 2003 - The Craft heritage of Oman. Dubai, Motivate Publishing. The InsideWood Working Group. 2004 - InsideWood database. Continuously updated, Raleigh, North Carolina State University. URL http://insidewood.lib.ncsu.edu/search.

Tengberg M. 2012 - Beginnings and early history of date palm garden cultivation in the Middle East. Journal of Arid Environments 86 (0) : 139-147.

Terral J.-F., Newton C., Ivorra S., Gros-Balthazard M., de Morais C.T., Picq S., Tengberg M. \& Pintaud J.-C. 2012 - Insights into the historical biogeography of the date palm (Phoenix dactylifera 
1.) using geometric morphometry of modern and ancient seeds. Journal of Biogeography, 39 (5) : 929-941.

Thomas R. 2011a - Anatomie comparée des palmiers: Identification-assistée par ordinateur, Applications en paléobotanique and en archéobotanique. Thèse de doctorat, Muséum national d'histoire naturelle, Paris.

Thomas R. 2011b - Palm-ID, a database to identify the palm stem anatomy with an expert system (Xper $\left.{ }^{2}\right)$. Continuously updated, Université Paris 6 - Muséum national d'Histoire naturelle, Paris. URL http://www.infosyslab.fr/Palm-ID/.

Thomas R. \& de Franceschi D. 2013 - Palm stem anatomy and Computer-aided identification: the Coryphoideae (Arecaceae). American Journal of Botany.

Thomas R., Tengberg M., Moulhérat C., Marcon V. \& Besenval R. - 2012. Analysis of a Protohistoric net from Shahi Tump, Baluchistan (Pakistan). Archaeological and Anthropological Sciences, 4 (1) : 15-23.

Tomlinson P.B. 1961 - Palmae. In Metcalfe C. (Ed.), Anatomy of the Monocotyledons, volume 2. Oxford, Oxford University Press.

Tomlinson P.B. 1964 - Stem Structure in Arborescent Monocotyledons. In Zimmermann M. H. (Ed.), Formation of Wood in Forest Tree. New York, Academic Press : 65-86.

Tomlinson P.B. 1990 - The Structural Biology of Palms. Oxford, Clarendron Press.

Tomlinson P.B., Horn J.W. \& Fisher J.B. 2011 - The Anatomy of Palms. Oxford, Oxford University Press.

Ung V., Dubus G., Zaragüeta-Bagils R. \& Vignes-Lebbe R. 2010 - Xper²: introducing e-taxonomy. Bioinformatics, 26(5) : 703-704. URL http://bioinformatics.oxfordjournals.org/ content/26/5/703.abstract.

de Vartavan C. \& Asensi Amoros V. 1997 - Codex des restes végétaux de l'Égypte ancienne. London, Triade Exploration.

Vignes-Lebbe R., Lebbe J., Dubus G., Chalubert A., Fradin H., Pavie B. \& Causse F. 2011 - Xper², version 2.2. Software. URL http://www.infosyslab.fr/lis/.

Waterhouse J. \& Quinn. C. 1978 - Growth patterns in the stem of the palm Archontophoenix cunninghamiana. Botanical Journal of the Linnean Society, 77 (2) : 73-93.

Zimmermann M. H. \& Tomlinson P. B. 1972 - The Vascular System of Monocotyledonous Stems. Botanical Gazette, 133(2) : 141-155. URL http://www.jstor.org/stable/247381

\section{RÉSUMÉS}

Cette étude présente les différents descripteurs anatomiques permettant d'identifier les stipes et les pétioles des différents genres de palmiers du Proche et Moyen Orient (Chamaerops, Hyphaene, Medemia, Nannorrhops, Phoenix). Depuis l'âge du Bronze, ces palmiers constituent une ressource végétale importante pour les populations habitant les déserts de ces régions. Les stipes de Phoenix et d'Hyphaene sont le plus souvent utilisés comme du matériau de construction pour les travaux architecturaux (poutres, piliers) et plus rarement comme combustible. Les pétioles et rachis ligneux de ces cinq genres sont fréquemment utilisés comme combustibles comme le montrent les nombreux fragments de charbon retrouvés dans les foyers des sites archéologiques. Ces parties sont également utilisées dans l'ameublement, pour la confection de charpentes et de 
petits bateaux de pêche. Cependant, jusqu'à récemment, ces restes de palmiers n'étaient identifiés qu'au niveau de la famille et habituellement interprété comme provenant du palmier dattier. Aucune étude n'avait fourni un moyen de discriminer: (i) les différents genres ; (ii) le stipe des parties ligneuses de la feuille (pétiole). Ce travail présente donc les descripteurs anatomiques qui permettent d'identifier les différents genres et les différentes structures. Cette distinction est à la fois proposée pour du matériel sec et carbonisé. Cette étude peut ainsi contribuer à la connaissance de l'évolution des pratiques humaines.

This study presents anatomical descriptors to identify stems and petioles of the Near and Middle East palms genera (Chamaerops, Hyphaene, Medemia, Nannorrhops, Phoenix). Since the Bronze Age, these palms are an essential plant resource for the populations of the hot deserts of these regions. Stems of Phoenix and Hyphaene are used as building materials in architectural work (beams and pillars) and in rare cases as fuel. Woody petioles and midribs of these five genera constitute a common source of fuel, as shown by the many palm fragments found in domestic hearths on archaeological sites. They are also transformed into furniture, small fishing boats or other carpentry works. However, until recently, fragments or remains were identified to the family level - usually interpreted as coming from the date palm - but no attempt had been made to distinguish: (i) the different genera; and (ii) the stem tissue from the woody parts of the leaf (petiole). This work provides positive anatomical descriptors to identify the different structures and the different genera both on carbonized and desiccated material. This study may thereby contribute to the knowledge of human practices of the past.

\section{INDEX}

Mots-clés : anatomie, stipe, pétiole, faisceau fibro-vasculaire, Chamaerops, Hyphaene, Medemia, Nannorrhops, Phoenix

Keywords : anatomy, stem, fibrovascular bundle

Index géographique: Proche-Orient, Égypte

\section{AUTEUR}

\section{ROMAIN THOMAS}

Muséum national d'histoire naturelle

UMR 7207 MNHN-CNRS-UPMC Centre de recherche sur la paléobiodiversité et les

paléoenvironnements. Département histoire de la Terre

8, rue Buffon, 75005 Paris, France

Tel

: +331407934 58; Fax: +33140793580

E-mail: thomas@mnhn.fr 